\title{
Roguing with Replacement in Perennial Crops: Conditions for Successful Disease Management
}

\author{
Mark S. Sisterson and Drake C. Stenger
}

United States Department of Agriculture-Agricultural Research Service, San Joaquin Valley Agricultural Sciences Center, Parlier, CA 93648. Accepted for publication 8 October 2012.

\begin{abstract}
Sisterson, M. S., and Stenger, D. C. 2013. Roguing with replacement in perennial crops: Conditions for successful disease management. Phytopathology 103:117-128.

Replacement of diseased plants with healthy plants is commonly used to manage spread of plant pathogens in perennial cropping systems. This strategy has two potential benefits. First, removing infected plants may slow pathogen spread by eliminating inoculum sources. Second, replacing infected plants with uninfected plants may offset yield losses due to disease. The extent to which these benefits are realized depends on multiple factors. In this study, sensitivity analyses of two spatially explicit simulation models were used to evaluate how assumptions concerning implementation of a plant replacement program and pathogen spread interact to affect disease suppression. In conjunction, effects of assumptions concerning yield loss associated with disease and rates of plant maturity on yields were simultaneously evaluated. The first model was used to evaluate effects of plant replacement on pathogen spread and yield on a single farm, consisting of a perennial crop monoculture. The second model
\end{abstract}

ABSTRACT evaluated effects of plant replacement on pathogen spread and yield in a 100 farm crop growing region, with all farms maintaining a monoculture of the same perennial crop. Results indicated that efficient replacement of infected plants combined with a high degree of compliance among farms effectively slowed pathogen spread, resulting in replacement of few plants and high yields. In contrast, inefficient replacement of infected plants or limited compliance among farms failed to slow pathogen spread, resulting in replacement of large numbers of plants (on farms practicing replacement) with little yield benefit. Replacement of infected plants always increased yields relative to simulations without plant replacement provided that infected plants produced no useable yield. However, if infected plants produced useable yields, inefficient removal of infected plants resulted in lower yields relative to simulations without plant replacement for perennial crops with long maturation periods in some cases.

Additional keywords: Citrus tristeza virus, Cocoa swollen shoot virus, huanglongbing disease, Xylella fastidiosa.
Removing infected plants (roguing) is often used to manage spread of plant pathogens $(1,5,13,16,19,46,52,56)$. In the case of perennial crops, rogued plants are often replaced with healthy plants. Roguing followed by replanting has two potential benefits. First, removing an infected plant eliminates a source of inoculum, potentially slowing pathogen spread. Second, infected plants may die or have reduced yield. Thus, replacing a diseased plant with a healthy plant may offset yield losses. While the potential benefits are enticing, whether or not roguing reduces losses depends on multiple factors. In this study, factors affecting successful implementation of a rogue and replace disease control strategy in a perennial cropping system are outlined and subsequent effects on pathogen spread and crop yield evaluated using spatially explicit simulation models.

A primary reason for removing infected plants is to eliminate inoculum sources. In this case, it is implicitly assumed that there is a risk of secondary pathogen spread. For vector-transmitted pathogens, risk of secondary pathogen spread depends on vector movement patterns, vector density within the crop, and role of the crop plant in the life cycle of the vector. For example, secondary spread of Cocoa swollen shoot virus (CSSV) may be common as cocoa is a primary host of mealybug vectors that may move between plants via an interlocking canopy (56). In contrast, some

Corresponding author: M. S. Sisterson; E-mail address: mark.sisterson@ ars.usda.gov

* The $\boldsymbol{e}$-Xtra logo stands for "electronic extra" and indicates that the online version contains one supplementary table.

http://dx.doi.org/10.1094/PHYTO-05-12-0101-R

This article is in the public domain and not copyrightable. It may be freely reprinted with customary crediting of the source. The American Phytopathological Society, 2013. plant pathogens are spread by vectors that make trivial movements into the crop and then leave. For example, in the Central Valley of California, the primary vector of Xylella fastidiosa (causal agent of Pierce's disease of grape and almond leaf scorch disease) is the green sharpshooter, Draeculacephala minerva $(12,48)$. This vector prefers grasses over grape and almond and is predominately found in permanent pastures and weedy alfalfa fields $(12,39,48)$, habitats that harbor plant species that serve as hosts of $X$. fastidiosa $(41,48)$. As a result, movement of green sharpshooters into almond or grape is transient and risk of secondary pathogen spread appears to be low $(12,29,47)$.

Presuming secondary pathogen spread occurs, the extent to which roguing slows disease progress depends on how rapidly infected plants are removed. However, there are a number of logistical issues associated with efficient identification of infected plants in large-scale agricultural operations. For example, disease surveys may be hampered by a lack of appropriate and/or costeffective diagnostic tests or personnel trained to recognize symptoms. Further, infected plants may continue to produce a useable yield before decline, making growers hesitant to remove diseased plants quickly. For example, farmers in Ghana are reluctant to remove CSSV-infected cocoa trees that are bearing pods and appear healthy (56). Consequently, there is often a considerable lag between infection and removal.

Decisions to rogue and replant may be made by growers independently or growers may act in concert over a large area. The degree of coordination among growers is likely to affect the extent to which pathogen spread is slowed. For example, management of huanglongbing (HLB) disease in Brazil was more successful on large farms than on small farms (6). Similarly, DzahiniObiatey et al. (17) hypothesized that roguing failed to slow spread 
of CSSV in Ghana due to a lack of coordinated effort among farmers, as cocoa farms are highly fragmented.

Replacing diseased plants with healthy plants may offset yield losses. In cases where plants die or produce no useable yield, the decision to replace diseased plants of a long-lived perennial crop is simple, as such plants have no value. However, some plant pathogens do not kill the host and have limited effects on yield $(14,46,47)$. For example, yields of almond trees infected with $X$. fastidiosa are reduced by only 20 to $40 \%$ relative to uninfected almond trees $(46,47)$. For some perennial crops, it may take years for a replacement plant to become fully productive $(18,32,33)$. As a result, a mature infected plant may be more productive over the remaining lifetime of the crop than an uninfected immature replant (46). Thus, yield benefits associated with replanting are likely to be related to time required for plants to achieve full production and extent of yield loss due to disease.

Roguing as a disease control strategy has received some theoretical attention. Previous models largely used differential equations to describe disease dynamics $(10,21,58)$. Here, a spatially explicit simulation model that captured key processes associated with primary and secondary pathogen spread was developed. Model assumptions were purposefully simple so that results would provide broad recommendations applicable to a wide array of systems. Farms were modeled as a grid of plants on an $x / y$ coordinate system. Primary and secondary pathogen spread followed transition rules and plant yields were assigned based on plant age and infection status. Simulations were run at two scales. First, effects of roguing and replanting were evaluated on a single farm assuming that inoculum sources for primary pathogen spread were located outside of the simulated farm but not otherwise explicitly designated. Subsequently, the model was expanded to consider a crop growing region of 100 farms arranged in a square grid (10 farms $\times 10$ farms) where rates of primary pathogen spread onto each farm were a function of disease incidence on neighboring farms. In this case, inoculum sources for primary pathogen spread were explicitly designated and replacement of infected plants on individual farms affected pathogen spread to neighboring farms.

The simulation approach taken here was similar to that used to develop guidelines for managing the evolution of resistance to insecticides by insects $(9,23,28,36,44,45,54,55)$ and discussed further by Peck (35). This approach entails simulating the management strategy under a wide range of conditions to identify the region of parameter space associated with effective disease control. Ultimately, simulation results cannot conclusively demonstrate the effectiveness of a management strategy without field testing. However, for plant pathogens that spread rapidly or are invasive, researchers often do not have the opportunity to conduct large-scale, long-term field studies that incorporate appropriate controls (i.e., treatments that are expected to have high levels of pathogen spread) prior to making management recommendations. Accordingly, the simulation results presented here should be viewed as a tool to aid discussion of potential disease management strategies and for prioritizing strategies for field testing.

\section{THEORY AND APPROACHES}

Single farm model. The model was written in $\mathrm{C}++$ using Microsoft Visual C++ (code available on request). The model was spatially explicit, with a farm defined as a square grid of plants with 75 rows and 75 plants per row $(75 \times 75=5,625$ plants; Table 1). For each plant, the model tracked location on an $x / y$ coordinate system, age, infection status, and yield based on age and infection status. The model assumed a perennial crop that was newly planted at the start of a simulation and followed the crop over 25 years with a time step equal to 1 year. Maturation periods of perennial crops vary. For example, short maturation times (1 to 2 years) are representative of crops such as banana which produce yield quickly, moderate maturation periods (4 to 6 years) are representative of crops such as grapes $(34,59)$, and long maturation periods are representative of some citrus, almond, and cocoa varieties (>10 years; 18,32,33). Accordingly, a parameter for crop maturation period $(M)$ was incorporated into the model. At time of planting, plants produced no yield and yield increased linearly from a minimum value of 0 to a maximum value of 1 when the crop reached maturity. Once a plant matured, the yield parameter based on maturity was held constant at 1 for the remainder of the simulation. For simulations of the single farm model, results using a short $(M=1$ year) and long $(M=12$ years $)$ plant maturation period were presented to illustrate effects of plant maturation period on simulation results.

Each year, each plant had a fixed probability of becoming infected due to primary pathogen spread ( $P$; Table 1$)$. To model this, a random number between 0 and 1 was obtained for each plant. If the random number was less than the probability that a plant was infected due to primary pathogen spread, the plant was infected; otherwise it remained uninfected. Infected plants could act as sources of inoculum for secondary pathogen spread $(S)$, beginning the next year after becoming infected. Accordingly, the latent period (time between infection by a pathogen and onset of infectivity; 25) was fixed at 1 year for all simulations. As with primary pathogen spread, secondary pathogen spread occurred with a fixed probability (Table 1). As plants were arranged in a square grid, infected plants typically had eight neighbors (except for plants on farm edges). For each plant that bordered an infected plant, a random number between 0 and 1 was obtained. If this number was less than the probability of secondary pathogen spread, the plant was infected. For healthy plants that bordered more than one infected plant, risk of infection due to secondary spread was multiplicative. For example, if a healthy plant bordered two infected plants, there were two opportunities for the healthy plant to become infected, each with probability $S$.

When considering values to use for rates of primary and secondary pathogen spread in simulations it is important to recognize that rates of primary and secondary pathogen spread within any given pathosystem are inherently variable and context dependent. For example, for vector-transmitted pathogens rates of primary spread onto a farm are a function of proximity to vector and inocula sources which vary over space and time. Similarly, rates of secondary pathogen spread are a function of a variety of factors including vector density, which varies based on the extent to which management tactics are applied to suppress vector populations. Accordingly, simulations of the single farm model used a wide range of values for primary $(P=0.01$ to 0.10$)$ and secondary pathogen spread $(S=0.01$ to 0.20$)$.

Annual yield of each plant was calculated based on plant age and infection status. Once a plant was infected, yield was proportionately reduced relative to an uninfected plant of the same age. Thus, yield loss due to infection $(Y)$ was described by a parameter that had a value between 0 (infected plant produced no yield) and 1 (plants were tolerant with yield unaffected by infection) that described relative yield of an infected plant compared with an uninfected plant. For simplicity, yields of infected plants were assumed to decline immediately after infection. Accordingly, the model assumed no incubation period (time between infection by a pathogen and onset of symptom expression; 25). For simulations, two values for yield loss associated with infection were used: $Y=0.00$ and 0.75 . With $Y=0.0$, infected plants produced no useable yield and were assumed to act as potential inoculum sources until removed. With $Y=0.75$, infected plants were assumed to produce some useable yield similar to what was observed for almond trees infected with $X$. fastidiosa $(46,47)$.

After yields were calculated, the last step of each year was to determine which infected plants were replaced with healthy plants. For each set of simulations, the probability of identifying and replacing an infected plant had a fixed probability $(R)$. Thus, for each 
infected plant a random number between 0 and 1 was obtained; if the random number was less than the probability that an infected plant was replaced, the plant was replaced. Four values for plant replacement rate were used in simulations: $R=0.00, R=0.25, R=$ 0.50 , and $R=1.0$ (Table 1 ). As plant replacement was modeled as a binomial probability, rates of plant replacement can be expressed as the average length of time (after infection) an infected plant remained on the farm before it was removed. Thus, with $R=0.00$, infected plants were never removed, with $R=0.25$, infected plants remained on the farm for an average of 4 years, with $R=0.50$, infected plants remained on the farm for an average of 2 years, and with $R=1.00$, infected plants were removed the year the plant was infected. If a diseased plant was replaced, it was assumed to be replaced by a healthy plant of age zero that produced no yield at the time of planting. As with plants present at the start of a simulation, yields of replants increased linearly, until maturity.

Multi-farm model. Effects of grower cooperation/compliance for a disease management strategy involving roguing and replacement were evaluated by extending the single farm model to consider a square grid of 100 farms $(10 \times 10$; Table 1$)$. Rules governing plant growth and secondary pathogen spread for each farm in the multi-farm model were identical to those for the single farm model. The main difference between the single farm and multi-farm model was on how primary pathogen spread was modeled. In the single farm model, probability of a plant becoming infected via primary pathogen spread was a fixed value designated at the start of a simulation. In the multi-farm model, probability of primary infection within each farm was a function of disease incidence on neighboring farms (as farms were arranged in a square grid, farms typically had eight neighbors; except for farms on the edge of the grid). Thus, in the multi-farm model, probability of primary pathogen spread varied among farms and over time. In each year, the probability that a plant on a farm located at coordinates $x, y$ was infected due to primary pathogen spread was determined by where $P_{x, y}$ was the probability that a plant on a farm located at coordinates $x, y$ was infected via primary pathogen spread; $I_{x, y}$ was the number of infected plants on a farm located at coordinates $x$, $y$; $T_{x, y}$ was the total number of plants on a farm located at coordinates $x, y$, and $w$ was a weighting factor that was varied in sensitivity analyses. For presentation, two values of the primary spread weighting factor $(w)$ were used $(w=0.15$ and 0.45$)$ in combination with two values for rate of secondary pathogen spread ( $S=0.01$ and 0.10 ). Accordingly, this allowed for comparison of model results with relatively slow primary and secondary pathogen spread ( $w=0.15, S=0.01)$ to model results with relatively rapid primary and secondary pathogen spread $(w=0.45$, $S=0.10)$.

At the start of each simulation, all farms were assumed to be newly planted and a fixed proportion of farms were designated to engage in roguing/replacement and referred to as "managed farms." Farms that were not designated as managed farms, did not remove or replace infected plants and were referred to as "unmanaged farms." The proportion of farms engaged in roguing/replacement was varied from 0 to 1 in sensitivity analyses (Table 1). For all simulations of the multi-farm model, initial disease incidence was $0.1 \%$ with infected plants randomly distributed among all 100 farms.

Simulation output. Output for the single farm model consisted of the percentage of extant plants infected in year 25 and the percentage of plants removed from the farm over all 25 years. As the percentage of plants removed was a cumulative total over all 25 years of production, values greater than $100 \%$ suggested that all plants on the farm were replaced and/or that some replants were repeatedly replaced. For the multi-farm model, output was the same as that for the single farm model except that the percentage of plants infected was tracked separately for managed and unmanaged farms.

To examine effects of assumptions concerning time to plant maturity $(M)$ and yield loss due to infection $(Y)$, lifetime farm yields

$$
P_{x, y}=\left(\frac{I_{x-1, y-1}+I_{x-1, y}+I_{x-1, y+1}+I_{x, y-1}+I_{x, y+1}+I_{x+1, y-1}+I_{x+1, y}+I_{x+1, y+1}}{T_{x-1, y-1}+T_{x-1, y}+T_{x-1, y+1}+T_{x, y-1}+T_{x, y+1}+T_{x+1, y-1}+T_{x+1, y}+T_{x+1, y+1}}\right) \times w
$$

TABLE 1. Parameters and values used in simulations of the single farm and multi-farm models

\begin{tabular}{|c|c|c|}
\hline Model & Parameter (symbol) & Values presented \\
\hline Single farm & $\begin{array}{l}\text { Number of farms } \\
\text { Number of plants per farm } \\
\text { Probability of primary spread per plant per year }(P) \\
\text { Probability of secondary spread per infected neighbor per year }(S) \\
\text { Latent period (time between infection and onset of infectivity) } \\
\text { Infectious period } \\
\text { Year maximum yield produced }(M) \\
\text { Yield of infected plants relative to uninfected plants }(Y) \\
\text { Incubation period (time between infection and yield decrease) } \\
\text { Probability of replacing an infected plant per year }(R)\end{array}$ & $\begin{array}{l}1 \\
5,625(75 \times 75) \\
0.0 \text { to } 0.1 \\
0.0 \text { to } 0.2 \\
1 \text { year } \\
\text { Until removed } \\
1,12 \\
0.0,0.75 \\
\text { Immediate } \\
0.0,0.25,0.5,1.0\end{array}$ \\
\hline Multi-farm & $\begin{array}{l}\text { Number of farms } \\
\text { Number of plants per farm } \\
\text { Number of plants in region } \\
\text { Initial percentage of plants infected } \\
\text { Probability of primary spread per plant per year }\left(P_{x, y}\right) \\
\text { Primary spread weighting factor }(w) \\
\text { Probability of secondary spread per infected neighbor per year }(S) \\
\text { Latent period (time between infection and onset of infectivity) } \\
\text { Infectious period } \\
\text { Year maximum yield produced }(M) \\
\text { Yield of infected plants relative to uninfected plants }(Y) \\
\text { Incubation period (time between infection and yield decrease) } \\
\text { Probability of replacing an infected plant per year }(R) \\
\text { Percentage of managed farms }\end{array}$ & $\begin{array}{l}100(10 \times 10) \\
5,625(75 \times 75) \\
562,500 \\
0.1 \\
\text { Equation } 1 \\
0.15,0.45 \\
0.01,0.1 \\
1 \text { year } \\
\text { Until removed } \\
1-16 \\
0.0,0.75 \\
\text { Immediate } \\
0.0 \text { to } 1.0 \\
20,80\end{array}$ \\
\hline
\end{tabular}

\footnotetext{
${ }^{a}$ For each simulation a percentage of farms were designated as managed or unmanaged. Managed farms replaced infected plants and unmanaged farms did not replace infected plants.
} 
were output. As the model determined yield of each plant in each year based on plant age and infection status, lifetime farm yields were determined by summing yields of all plants on the farm over all years of the 25 year crop cycle. Lifetime farm yields decreased as plant maturation time $(M)$ increased. To standardize yield results, yields in absence of disease over the 25 year crop cycle were determined for each plant maturation time evaluated. Yield from each simulation was expressed as a percentage of the maximum possible yield (relative yield) observed in the absence of disease based on plant maturation time. For the multi-farm model, relative yields were tracked separately on managed and unmanaged farms.

Three sets of simulations were completed, each set building off the previous. The first set of simulations examined effects of plant replacement on disease incidence and yield in the single farm model with primary pathogen spread only. The second set examined effects of plant replacement on disease incidence and yield in the single farm model with both primary and secondary pathogen spread. The final set of simulations examined effects of plant replacement and percentage of farms replacing infected plants on disease incidence and yield in the multi-farm model. As the models were stochastic, 16 replicates for each parameter combination were completed and means were presented. Due to space limitations, only a subset of all simulations conducted could be presented. As a result, effects presented for some parameters on simulation outcome were limited to a single representative value or the comparative effects of a high and low value (Table 1). Nonetheless, results from a total of 8,192 simulations representing 512 unique parameter combinations are presented.

\section{RESULTS}

Single farm, primary pathogen spread only. Disease incidence after 25 years decreased as plant replacement rate increased (Fig. 1A). As there was no secondary pathogen spread, replacing
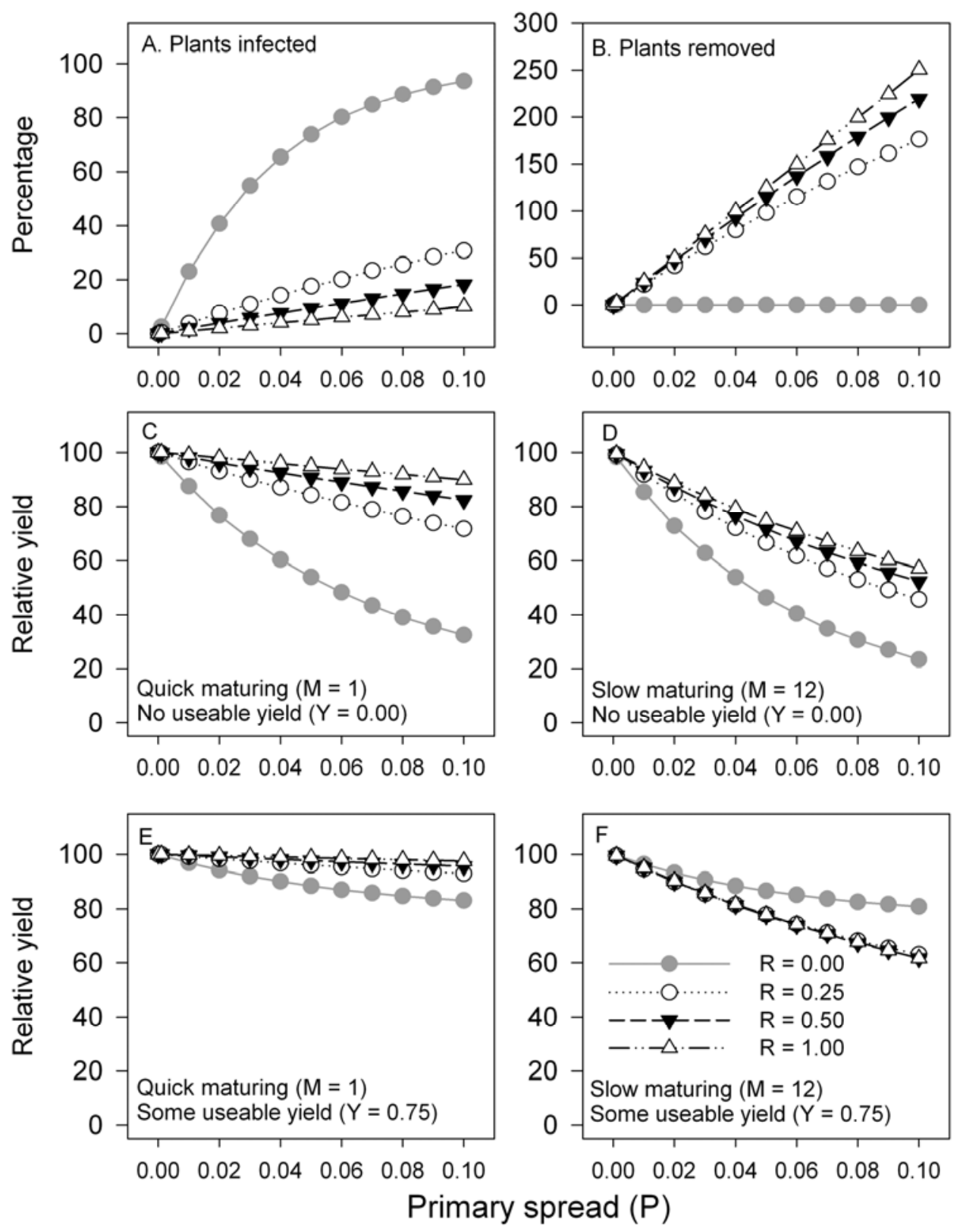

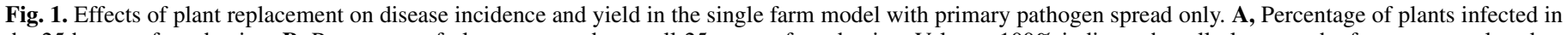

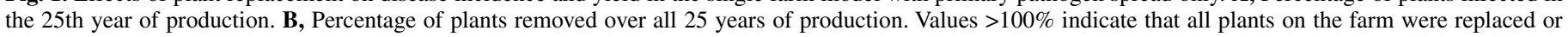

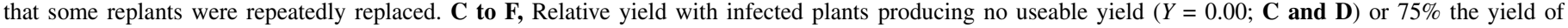

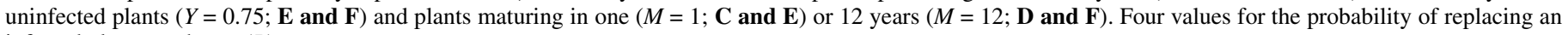
infected plant are shown $(R)$. 
infected plants did not alter the rate of infection from year to year. Accordingly, the percentage of plants replaced over the life of the crop was similar for all plant replacement rates $(R>0$; Fig. 1B). With a high rate of plant replacement $(R=1.0)$, the percentage of plants infected equaled the rate of primary pathogen spread (Fig. 1A). Disease incidence increased as plant replacement rate decreased because infected plants remained on farms for longer periods before they were removed (Fig. 1A).

With primary pathogen spread only, increasing plant replacement rate increased yields provided that infected plants produced no useable yield ( $Y=0.00$; Fig. $1 \mathrm{C}$ and $\mathrm{D})$ or had short maturation periods ( $M=1$; Fig. 1E). However, with infected plants producing $75 \%$ of the yield of uninfected plants $(Y=0.75)$ and long plant maturation periods $(M=12)$, replacing infected plants $(R \geq$ $0.25)$ reduced yields relative to simulations without plant replacement $(R=0.00$; Fig. $1 \mathrm{~F})$.

Single farm, primary and secondary pathogen spread. Disease incidence at the end of the 25 year crop cycle decreased as plant replacement rate increased (Fig. 2A). With a high plant replacement rate $(R=1.0)$, infected plants were removed the same year as becoming infected, thereby preventing secondary spread of the pathogen. Accordingly, with a high plant replacement rate $(R=1.0)$, disease incidence equaled the rate of primary pathogen spread (0.01); regardless of the rate of secondary pathogen spread used for a simulation (Fig. 2A). With a high plant replacement rate $(R=1.0)$, disease incidence not only remained low (Fig. 2A), but the percentage of plants replaced also was low as secondary pathogen spread was effectively halted (Fig. 2B). With moderate $(R=0.50)$ and low $(R=0.25)$ rates of plant replacement, infected plants remained in the field for an average of 2 or 4 years, respectively. As a result, with moderate $(R=0.50)$ and low $(R=$ 0.25 ) rates of plant replacement, plants infected via primary pathogen spread were not removed before acting as inoculum sources for secondary pathogen spread. Accordingly, with moderate $(R=$ $0.50)$ and low $(R=0.25)$ rates of plant replacement, disease incidence increased with the rate of secondary pathogen spread (Fig. $2 \mathrm{~A})$. Failure to slow secondary pathogen spread with moderate $(R=0.50)$ and low $(R=0.25)$ rates of plant replacement resulted
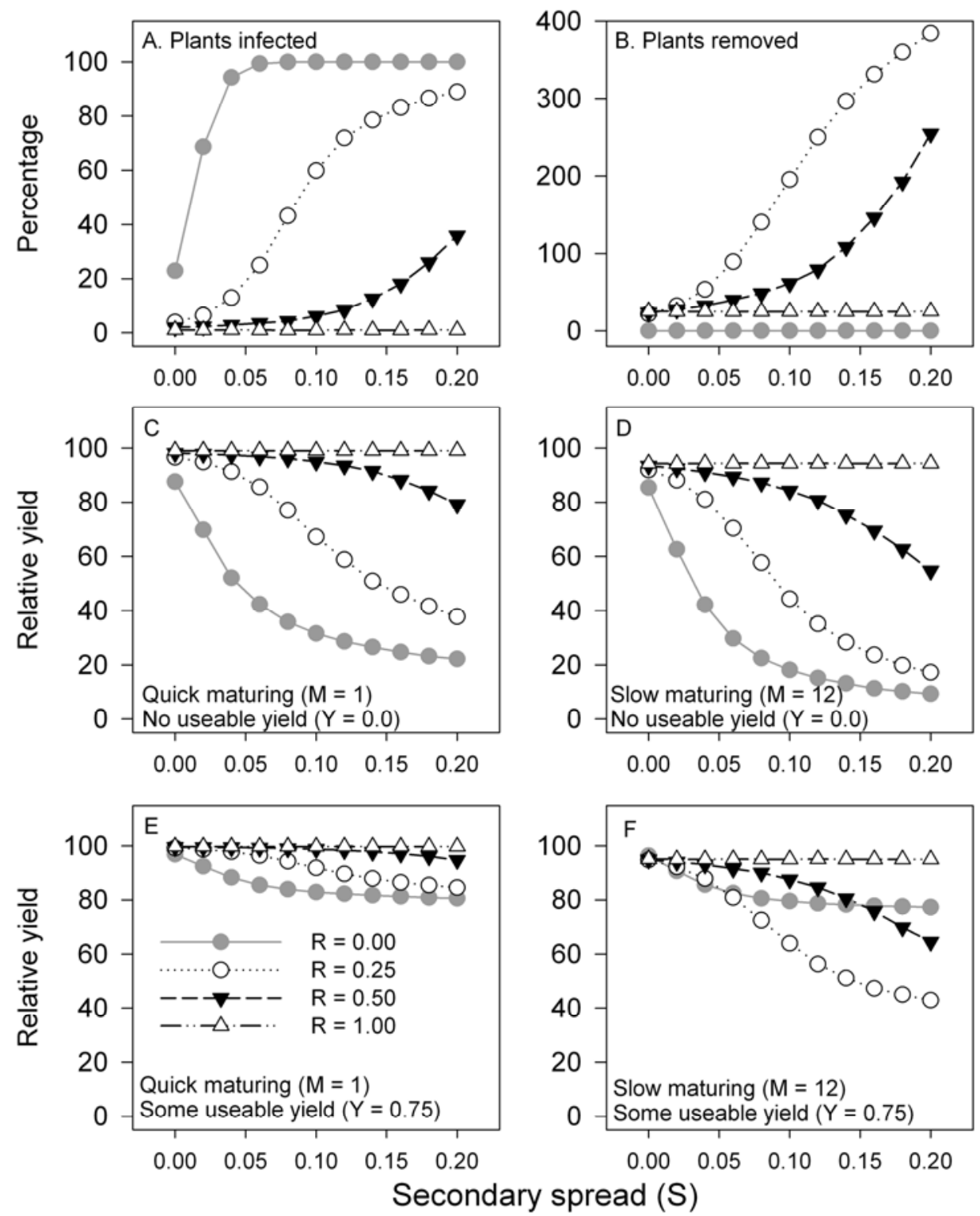

Fig. 2. Effects of plant replacement on disease incidence and yield in the single farm model with primary and secondary pathogen spread. A, The percentage of plants infected in the 25th year of production. B, The percentage of plants removed over all 25 years of production. Values $>100 \%$ indicate that all plants on the farm were replaced or that some replants were repeatedly replaced. $\mathbf{C}$ to $\mathbf{F}$, Relative yield with infected plants producing no useable yield $(Y=0.00 ; \mathbf{C}$ and $\mathbf{D})$ or $75 \%$ the yield of uninfected plants $(Y=0.75 ; \mathbf{E}$ and $\mathbf{F})$ and plants maturing in one $(M=1 ; \mathbf{C}$ and $\mathbf{E})$ or 12 years $(M=12 ; \mathbf{D}$ and $\mathbf{F})$. For all simulations primary spread $(P)$ was assigned a value of 0.01 . Four values for the probability of replacing an infected plant are shown $(R)$. 
in a high percentage of plants replaced during the 25 year crop cycle (Fig. 2B).

With both primary and secondary pathogen spread, effects of plant replacement on yield (Fig. 2C to F) reflected effects of plant replacement on disease incidence (Fig. 2A) and percentage of plants replaced (Fig. 2B). Under such conditions, high yields were associated with parameter combinations that resulted in low disease incidence and replacement of few plants. With infected plants producing no useable yield ( $Y=0.00$; Fig. 2C and D) or short plant maturation times $(M=1$; Fig. $2 \mathrm{C}$ and $\mathrm{E})$, yields with plant replacement $(R \geq 0.25)$ were always greater than yields without plant replacement ( $R=0.00$; Fig. $2 \mathrm{C}$ to $\mathrm{E})$. However, with infected plants producing $75 \%$ of the yield of uninfected plants $(Y=0.75)$ and long plant maturation times $(M=12)$, yields with plant replacement $(R \geq 0.25)$ were not always greater than yields without plant replacement $(R=0.00$; Fig. 2 F $)$. Specifically, with infected plants producing $75 \%$ of the yield of uninfected plants $(Y=0.75)$ and a high plant replacement rate $(R=1.0)$, yields approached the maximum possible value (Fig. $2 \mathrm{~F}$ ) as secondary pathogen spread was effectively halted (Fig. 2A) and few plants were replaced (Fig. 2B). In contrast, with moderate $(R=0.50)$ or low $(R=0.25)$ plant replacement rates, secondary pathogen spread was not halted and the percentage of plants replaced was often high (Fig. 2B). As a result, with infected plants producing $75 \%$ of the yield of uninfected plants $(Y=0.75)$ and a long plant maturation time $(M=12)$, lifetime farm yields were lower with moderate $(R=0.50)$ and low $(R=0.25)$ rates of plant replacement compared with simulations without plant replacement $(R=0.00)$ for some levels of secondary pathogen spread (Fig. 2F).

Multi-farm, effects of plant replacement on disease incidence. In the multi-farm model, rate of primary pathogen spread onto any single farm was a function of disease incidence on neighboring farms. Accordingly, in the multi-farm model, replacing infected plants had two effects. First, replacing infected plants reduced secondary pathogen spread on managed farms as seen in the single farm model (Fig. 2A), provided that the probability of replacing an infected plant was sufficiently high. Second, replacing infected plants decreased rates of primary pathogen spread to neighboring farms potentially benefiting both managed and unmanaged farms, although the extent of this effect depended on the rate of plant replacement and the percentage of farms replacing infected plants (compare Fig. 3A, C, and E to Fig. 3B, D, and $\mathrm{F}$ ).

With $20 \%$ of farms replacing infected plants, most farms were unmanaged and had high disease incidence (Fig. 3C), contributing to high rates of primary pathogen spread among farms. Thus, with a minority of farms replacing infected plants, replacing infected plants reduced rates of secondary pathogen spread on managed farms, but had little effect on rates of primary pathogen spread among farms. As a result, with $20 \%$ of farms replacing infected plants, plant replacement was more effective at reducing disease incidence on managed farms with a low value for primary pathogen spread weighting factor $(w=0.15)$ than with a high value for primary pathogen spread weighting factor $(w=0.45$; Fig. 3A). With only $20 \%$ of farms replacing infected plants, rates of primary pathogen spread were high such that on managed farms replants were often quickly infected, resulting in replacement of large numbers of plants (Fig. 3E).

With $80 \%$ of farms replacing infected plants and high rates of plant replacement, secondary pathogen spread on managed farms was reduced and primary pathogen spread among all farms was regionally suppressed. As a result, with $80 \%$ of farms replacing infected plants, disease incidence on managed farms decreased to low levels as plant replacement rate increased (Fig. 3B). Regional suppression of primary pathogen spread among farms also resulted in lower disease incidence on unmanaged farms, provided that rates of secondary pathogen spread were low $(S=0.01$; Fig. $3 \mathrm{D})$. With a majority of farms replacing infected plants and high rates of plant replacement, pathogen spread was not only effectively suppressed (Fig. 3B), but this degree of suppression was accomplished with replacement of a relatively small number of plants (Fig. 3F). A high plant replacement rate was critical to observing the aforementioned effect as inefficient removal of infected plants, even with a majority of farms engaged in management, resulted in replacement of large numbers of plants (Fig. $3 \mathrm{~F}$ ), with little reduction in disease incidence (Fig. 3B) particularly with high rates of secondary pathogen spread $(S=0.10)$.

Multi-farm, effects of plant replacement on yield. Effects of plant replacement and percentage of farms replacing infected plants on managed farm yields (Fig. 4) were directly related to effects of plant replacement on disease incidence (Fig. 3A and B) and the percentage of plants replaced (Fig. 3E and F). In general, yields on managed farms were higher with parameter combinations that resulted in low disease incidence and replacement of few plants (compare Fig. 3A, B, E, and F to Fig. 4).

With infected plants producing no useable yield $(Y=0.00)$, replacing infected plants $(R>0.00)$ always increased yield on managed farms relative to simulations without plant replacement ( $R=0.00)$, although yield benefits increased as the plant replacement rate increased and as the percentage of farms replacing infected plants increased (Fig. 4A and B). With infected plants producing $75 \%$ of the yield of uninfected plants $(Y=0.75)$, replacing infected plants $(R>0.00)$ did not always increase yields on managed farms relative to simulations without plant replacement $(R=0.00$; Figs. $4 \mathrm{C}$ and $\mathrm{D}$ and 5$)$. With infected plants producing $75 \%$ of the yield of uninfected plants $(Y=0.75)$ and $20 \%$ of farms replacing infected plants, replacing infected plants often resulted in decreased yields on managed farms relative to simulations without plant replacement (Fig. 4C), with yield reductions increasing as plant maturation period increased (Fig. 5). This occurred due to the large number of plants replaced on managed farms when only $20 \%$ of farms replaced infected plants (Fig. 3E). In contrast, with infected plants producing $75 \%$ of the yield of uninfected plants $(Y=0.75)$ and $80 \%$ of farms replacing infected plants, plant replacement generally increased yields provided that the probability of replacing an infected plant was high (Figs. 4D and 5). This occurred because with a high percentage of managed farms and high rates of plant replacement, primary pathogen spread was suppressed at the regional scale and secondary pathogen spread was suppressed on managed farms, resulting in replacement of few plants (Fig. 3F).

Effects of plant replacement on unmanaged farm yields reflected effects of plant replacement on disease incidence on unmanaged farms. In such cases, higher yields were associated with parameter combinations that resulted in lower disease incidence (compare Fig. 3C and D to Fig. 6). With $20 \%$ of farms replacing infected plants, plant replacement had little effect on disease incidence (Fig. 3C) or yield on unmanaged farms (Fig. 6A and $\mathrm{C})$, regardless of the effects of infection on yield. In contrast, with $80 \%$ of farms replacing infected plants and high rates of plant replacement, primary pathogen spread was regionally suppressed (Fig. 3B and D). Accordingly, with $80 \%$ of farms replacing infected plants and high rates of plant replacement, plant replacement on managed farms also increased yields on unmanaged farms, particularly if secondary pathogen spread was low $(S=$ 0.01 ; Fig. $6 \mathrm{~B}$ and D).

\section{DISCUSSION}

Model results and field observations. Results of this simulation study provide insight into conditions associated with successful disease suppression and yield optimization due to roguing and replacement of infected plants. Specifically, efficient replacement of infected plants (Figs. 2 and 3 ) combined with a high degree of compliance among farms (Fig. 3B) effectively slowed pathogen spread, which in turn resulted in replacement of fewer plants 
(Figs. 2B and 3F) and increased yields (Fig. 2C to F and Fig. 4B and D). In contrast, inefficient replacement of infected plants (Figs. 2 and 3) and/or limited compliance among farms (Fig. 3A) failed to slow pathogen spread, which in turn resulted in replacing large numbers of plants on managed farms (Figs. 2B and 3E) with little yield benefit (Figs. 2C to F and 4A and C). Furthermore, with inefficient plant replacement and infected plants producing $75 \%$ of the yield of uninfected plants, plant replacement often resulted in lower yields than when infected plants were never replaced (Figs. 4C and D and 5), a situation where growers actively engaged in disease control faired more poorly than their neighbors making no effort to control disease (compare Fig. 4C and D to Fig. 6C and D).

To contextualize simulation results, perennial cropping systems that used roguing as a management strategy are discussed below. These comparisons serve to illustrate that parameters identified as critical to success of roguing with replacement in simulations appear to be important in real world systems and that application of the overarching conclusions from the model are relevant. Estimates of biological parameter values for each of the systems discussed are available online as Supplementary Table S1. As the models made many generalized assumptions, some discussion of perspective is warranted. The strength of using generalized assumptions lies in the ability to make broad conclusions and look for commonalities across systems. The weakness of this approach is that it easy to identify model assumptions that are an oversimplification or to question the appropriateness of a particular parameter value relative to a specific system. Recognizing the trade-off between broad applicability and specificity is important. Accordingly, interpretation of model results should focus on factors that are likely to affect the success of roguing across a wide range of conditions, rather than subtle differences in assumptions or parameter values that are unlikely to affect the overall conclusions regarding the success or failure of roguing.

In California, key vectors of $X$. fastidiosa vary by region, as do characteristics of $X$. fastidiosa spread $(24,29,49)$. In the Central
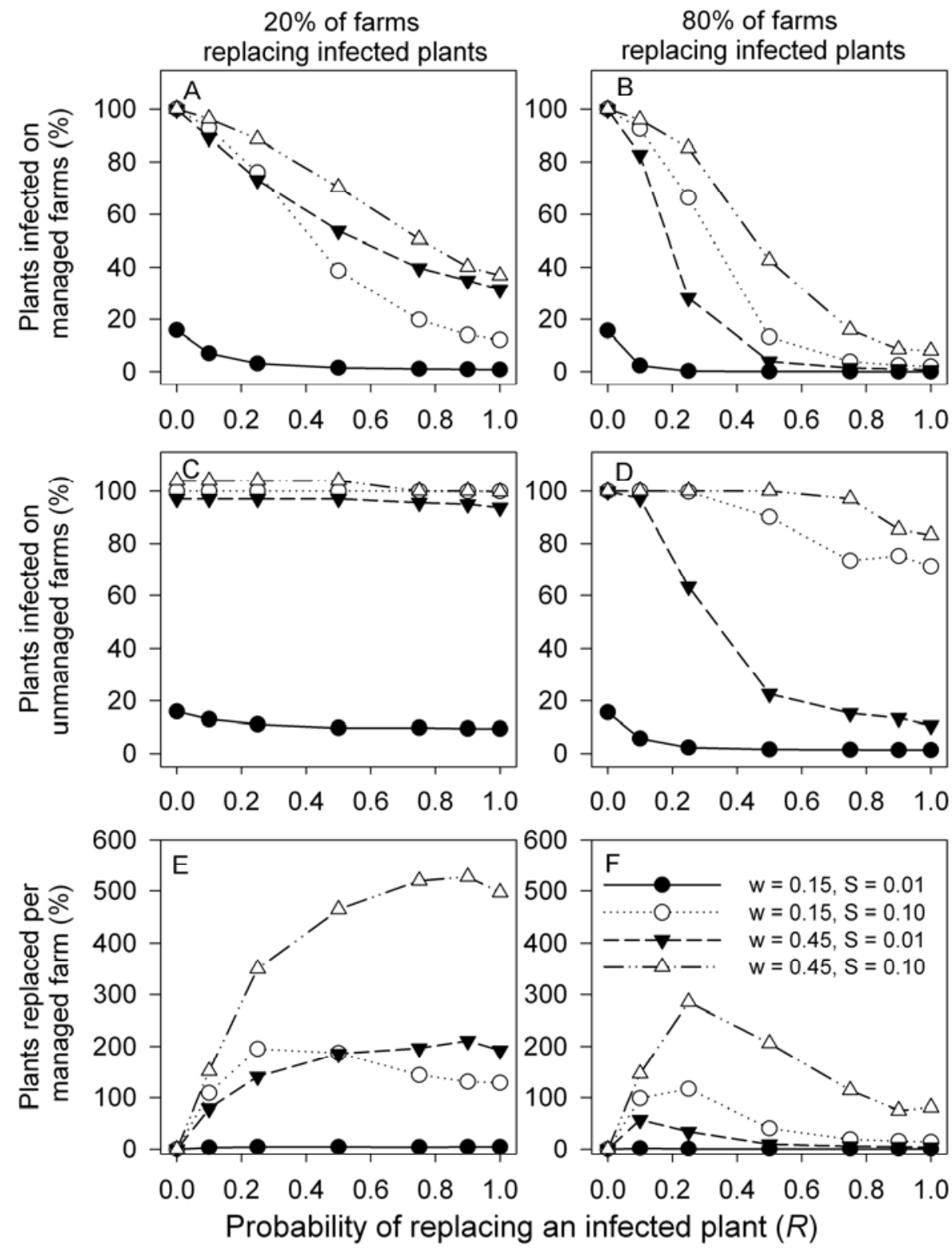

Fig. 3. Disease incidence on managed (A and B) and unmanaged (C and D) farms in the 25th year of production as a function of primary spread weighting factor $(w)$, rate of secondary spread $(S)$, and rate of plant replacement $(R)$ with $20 \%$ of farms replacing infected plants (A and C) or $80 \%$ of farms replacing infected plants (B and D). Percentage of plant replaced over all 25 years of production per managed farm with 20\% of farms replacing infected plants (E) or 80\% of farms replacing infected plant $(\mathbf{F})$. Values of the percentage of plants replaced per managed farm that exceed 100\% indicate that all plants on managed farms were replaced or that some replants were repeatedly replaced. With $R=0.00$, no farms replaced infected plants. 
$20 \%$ of farms replacing infected plants

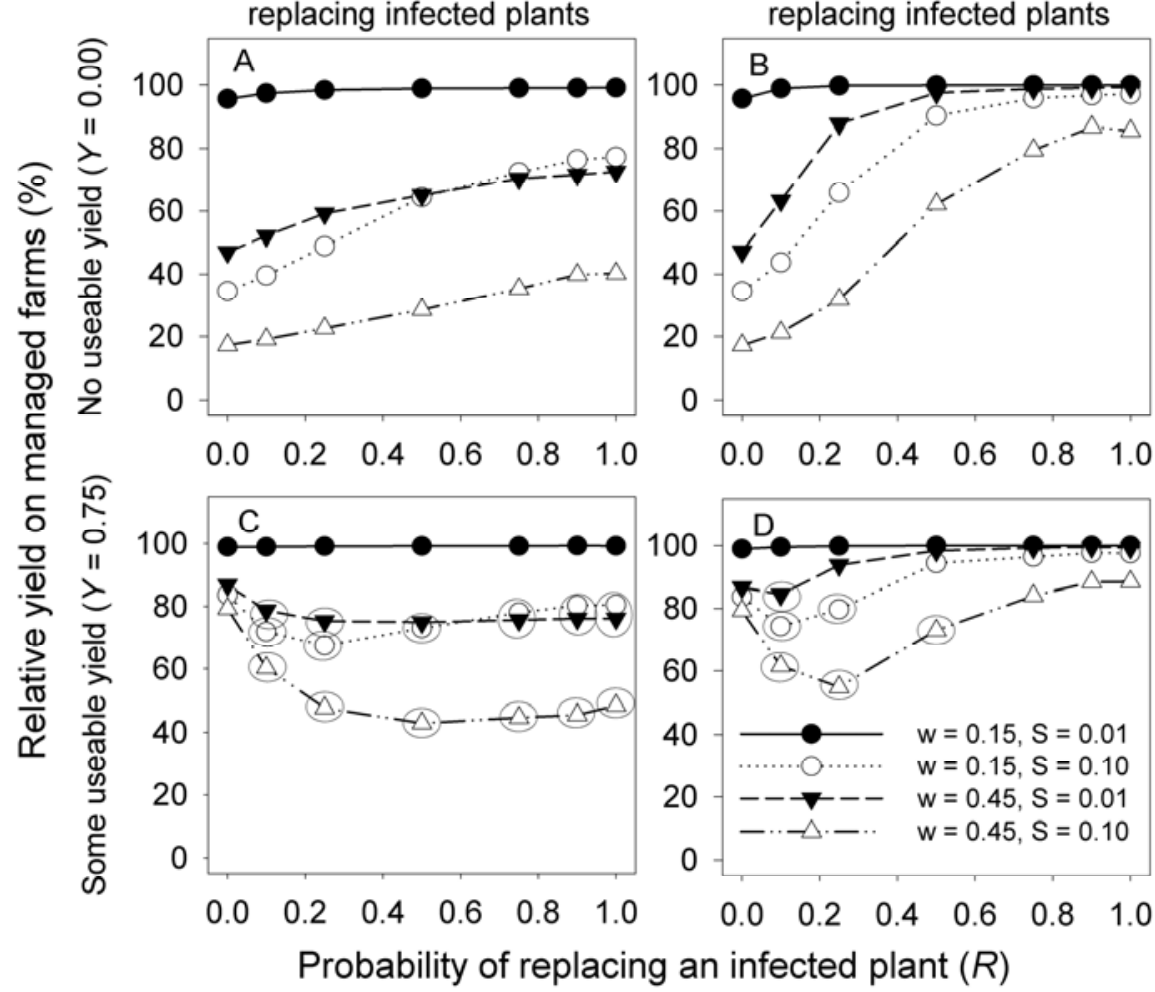

Fig. 4. Effects of plant replacement on managed farm yields with infected plants producing no useable yield $(Y=0.00 ; \mathbf{A}$ and $\mathbf{B})$ or infected plants producing $75 \%$ of the yield of an uninfected plant $(Y=0.75 ; \mathbf{C}$ and $\mathbf{D})$ and with $20 \%$ of farms replacing infected plants (A and $\mathbf{C})$ or $80 \%$ of farms replacing infected plants $(\mathbf{B}$ and D). In all panels, primary spread weighting factor $(w)$, rate of secondary spread $(S)$, and plant replacement rate $(R)$ were varied. For all simulations plant maturation time $(M)$ was 12 . Circled values indicate simulations where relative yields with plant replacement $(R>0.00)$ were less than relative yields without plant replacement $(R=0.00)$. With $R=0.00$, no farms replaced infected plants.

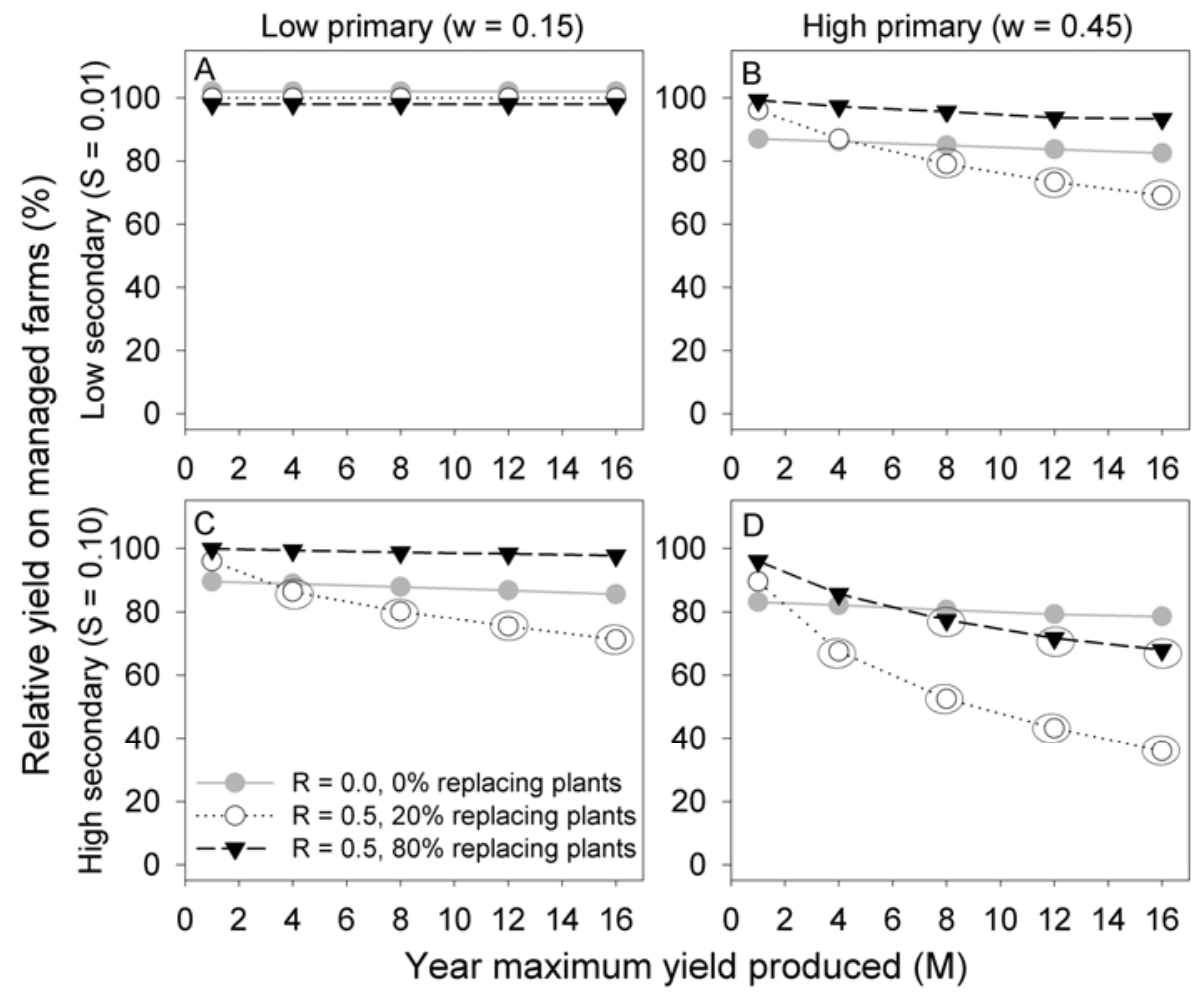

Fig. 5. Effects of plant maturation period on managed farm yields with infected plants producing $75 \%$ of the yield of uninfected plants $(Y=0.75)$. Relative yields on managed farms with low primary $(w=0.15)$ and secondary $(S=0.01)$ spread $(\mathbf{A})$, high primary $(w=0.45)$ and low secondary $(S=0.01)$ spread $(\mathbf{B})$, low primary $(w=0.15)$ and high secondary $(S=0.10)$ spread $(\mathbf{C})$, and high primary $(w=0.45)$ and secondary $(S=0.10)$ spread $(\mathbf{D})$. For all panels, results without plant replacement $(R=0.0$ on all farms) and with moderate plant replacement $(R=0.5)$ on 20 and $80 \%$ of farms are shown. Circled values indicate simulations where relative yields with moderate plant replacement $(R=0.50)$ were less than relative yields without plant replacement $(R=0.00)$. 
Valley of California, X. fastidiosa infection of grapevines and almonds is largely due to movement of green sharpshooters from irrigated pastures or weedy alfalfa fields $(12,39,48)$, habitats that harbor plant species that are hosts of $X$. fastidiosa $(41,48)$, into vineyards or almond orchards $(8,12,29)$. While green sharpshooters are routinely caught on traps placed on vineyard and orchard borders, populations are generally not found within vineyards or orchards $(8,12)$ as grapevines and almond trees are considered occasional hosts (39). Similar to simulations assuming primary pathogen spread only (Fig. 1A), roguing of Pierce's disease affected vines in the Central Valley of California had no effect on spread of $X$. fastidiosa within vineyards (29). Although both crops are long-lived and require multiple years to reach maturity, effects of $X$. fastidiosa infection on almond trees and grapevines differ. Pierce's disease may be lethal (24) whereas almond leaf scorch-affected trees continue to produce a useable yield for years after infection $(46,47)$. As a result, in areas where the green sharpshooter is the primary vector for both crops, recommendations for plant replacement differ. As seen in simulations, there is economic incentive to remove infected (dead) grapevines from vineyards even in the absence of secondary pathogen spread, as replacement vines will contribute to future yields (Fig. 1D). In contrast, decisions regarding removal of $X$. fastidiosa infected almond trees depend largely on whether the orchard will remain in place for a sufficient period of time for replacement trees to mature to a point where they will out-produce infected trees (Fig. 1F; 46,47).

Beginning in the 1930s, citrus in California was affected by quick decline disease caused by Citrus tristeza virus (CTV) infection of sweet orange scions grafted onto sour orange rootstock (5). In response, growers adopted use of a CTV-tolerant rootstock and, in cooperation with the state of California, instituted an eradication policy in which CTV-infected trees were identified and removed. However, most resident CTV strains in California cause mild or no disease symptoms on citrus grafted on tolerant rootstocks $(5,37)$ making growers reluctant to remove CTV-infected trees. As a consequence, participation in eradication efforts by five contiguous pest control districts in Central California was not uniform. Specifically, two of five pest control districts, representing $45 \%$ of the citrus acreage in Central California, opted to not participate in eradication efforts (60). The three participating districts engaged in roguing/replacement from 1995 until 2007 and 2008 when the program was abandoned as disease incidence within eradication zones had risen to levels where eradication was considered impractical (5). Simulations suggest two factors may have contributed to failure of roguing/replacement to suppress CTV incidence within eradication zones. First, eradication zones bordered citrus growing areas not engaged in eradication, creating a situation analogous to simulations with a minority of growers complying with a roguing/replacement program (Fig. 3A, C, and E). Further, early diagnosis of CTV infection was inefficient. Studies indicated that CTV infection may be undetectable via ELISA (the primary detection method during the eradication program) for up to 2 years postinfection, during which vectors may be able to acquire and transmit the virus (26). Accordingly, plant replacement rates were at best moderate $(R \leq 0.50)$. In response, a new management strategy has been advocated (5): targeted removal of trees infected with virulent (but uncommon) CTV strains causing significant disease regardless of rootstock. The model indicates that success of the targeted approach to eliminate virulent strains will depend largely on a sufficiently high level of grower compliance and prompt identification/removal of trees infected with virulent strains.

HLB disease is a worldwide threat to citrus production. The disease was reported to occur in Brazil in 2004 and Florida in 2005 (25). In both locations, the presumptive causal agent(s) ('Candidatus Liberibacter asiaticus' and ' $\mathrm{Ca}$. L. americanus' in Brazil; ' $C a$. L. asiaticus' only in Florida) has spread to most citrus production areas $(6,51)$. Infected groves appear to be important sources of inoculum for primary pathogen spread into neigh-

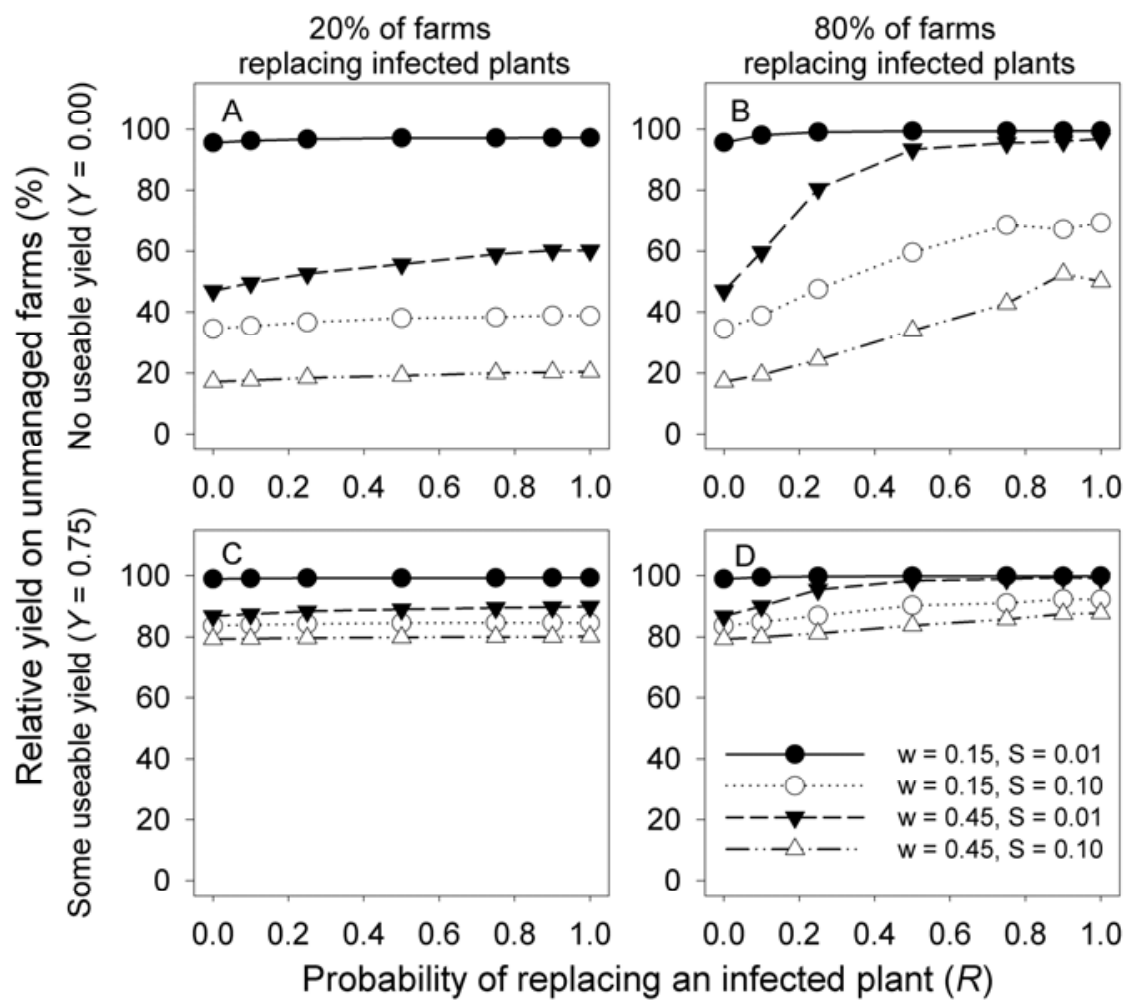

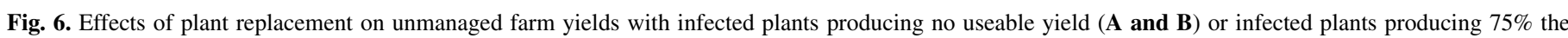

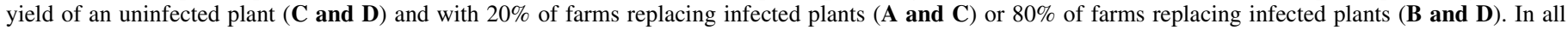

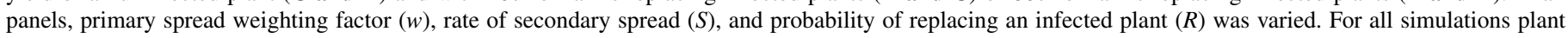
maturation time $(M)$ was 12 . With $R=0.00$, no farms replaced infected plants. 
boring groves and within groves there is evidence of secondary pathogen spread (25). Farm level experiments in Brazil found that successful management of HLB via roguing/replacement and vector control was positively associated with grove size and distance from unmanaged groves (6). Increasing grove size and distance from unmanaged groves is analogous to increasing the percentage of managed farms in the multi-farm model (Fig. 3). Despite evidence supporting regional management of HLB in Brazil, only $35 \%$ of citrus acreage is actively engaged in management (6). In Florida, management of HLB also may be impacted by a lack of large-scale coordination/compliance. Two factors contribute to a lack of large-scale coordination/compliance in Florida. First, as of 2009 there were 57,650 abandoned hectares of citrus in Florida which have been documented to serve as a source of vectors and $C a$. L. asiaticus $(7,57)$. Second, some growers are attempting to keep HLB-affected groves productive via fertilizer treatments $(50,51)$, although recent evidence suggests that fertilizer treatments may be ineffective (27). From a regional and long-term perspective, maintaining highly affected groves via fertilizer treatments is likely to reduce efficacy of management on neighboring farms, although the extent of this effect depends on the percentage of unmanaged farms and the degree to which primary pathogen spread among farms can be suppressed by reducing vector populations (Fig. 3).

Roguing followed by replacement has been used to manage spread of CSSV among cocoa plantings in Ghana. Specifically, CSSV was first reported in Ghana in 1936 and an eradication campaign was begun by 1946 (56). The eradication program is ongoing, although there have been periods of disruption and protocols occasionally have been modified $(17,56)$. Primary spread of CSSV is recognized to originate from older infected plantings and secondary pathogen spread occurs due to movement of mealybug vectors among plants within plantings (17). During eradication attempts, entire plantings were replaced often with improved germplasm. However, infected trees were often replaced slowly (e.g., $R$ was low) as cocoa maintains some degree of productivity after infection (56). Further, replaced plantings often bordered plantings that contained diseased trees that were not replaced (16). For example, 12,447 CSSV outbreaks were identified in the eastern region of Ghana between 2006 and 2010. During this period, only $890(7 \%)$ outbreaks were replanted leaving an estimated 11,957,300 CSSV-infected trees in the field (15). Despite removal of millions of CSSV infected trees in Ghana, success has been limited $(17,56)$. This observation is reflected in simulations which indicate that huge numbers of trees can be replaced (Fig. 3E and F) with little impact on disease incidence (Fig. 3A and B) when a minority of growers replace trees or when plant replacement is inefficient. More recent eradication protocols used in the Western Region of Ghana advocate distancing new plantings from potential sources of infection via barriers of CSSV immune crops (16).

Consideration of model assumptions. The models used here were purposefully simple so that the results would be broadly applicable. Thus, it is important to consider effects of simplifying assumptions on interpretation of model results. In simulations, the latent period (time between infection by a pathogen and onset of infectivity; 25) was fixed at 1 year. Similarly, the model(s) assumed no incubation period (time between infection by a pathogen and onset of symptom expression; 25) as yields of infected plants declined immediately. Latent and incubation periods may vary from months to years $(5,25,26)$ and the lengths of each period are likely to have important effects on pathogen spread and/or yield. For example, the time-scale over which removal of an infected plant is defined as "efficient" increases with latent period. Likewise, infected plants with a brief incubation period are likely to be removed sooner than infected plants with a protracted incubation period as infected plants with clear visual symptoms are more easily detected than asymptomatic plants.
Latent periods for pathogens such as CTV, CSSV, and ' $\mathrm{Ca}$. Liberibacter spp.' appear to be shorter than incubation periods $(5,25,26,56)$. Accordingly, efficient removal of plants affected by CTV, HLB, and CSSV is hampered by the fact that plants may serve as an acquisition source before symptoms are apparent.

In simulations with infected plants producing no useable yield $(Y=0.00)$, infected plants did not die and continued to act as inoculum sources for secondary pathogen spread until removed. In some cases, infected plants may die $(4,22)$ or may be less attractive to vectors than healthy plants $(20,42)$. For most vector transmitted pathogens, dead plants do not serve as a source of inocula. In such cases, plant death can be viewed as a form of roguing that does not require any action on the part of a grower. Simulations assuming that infected plants died within 4,6 , or 10 years after infection were conducted using the multi-farm model (data not shown). Results indicated that roguing was more effective at suppressing pathogen spread as the average lifespan of infected plants decreased.

For all simulations, infected plants were replaced on a plant-byplant basis. Specifically, the model simulated a scenario where farms were surveyed at the end of each year and if an infected plant was detected it was removed. However, alternative plant replacement rules could be considered. For example, Thresh and Owusu (56) advocated removing cocoa plants infected with CSSV and all plants immediately adjacent to an infected plant as plants neighboring infected plants are likely already infected but not symptomatic. In France, decisions concerning plant replacement in peach orchards affected by Plum pox virus strain $\mathrm{M}$ depend on disease incidence (13). Specifically, with incidence $<10 \%$, individual infected trees were removed similar to simulations presented in this study. However, with incidence $>10 \%$, entire orchards were removed. The model presented here is sufficiently flexible, that such plant replacement rules could be simulated and it is likely that evaluation of different plant replacement rules may find that different approaches are more suitable under different conditions.

Assumptions concerning inoculum sources for primary pathogen spread differed for the single farm and multi-farm models. The single farm model did not explicitly designate inoculum sources contributing to primary pathogen spread. Consequently, the single-farm model is suitable for considering spread of plant pathogens regardless of primary inoculum sources. In contrast, the multi-farm model explicitly designated inoculum sources as other farms producing the same crop. Accordingly, application of the results from the multi-farm model is more limited than those of the single farm model. However, the observation that efficacy of plant replacement decreased as percentage of unmanaged farms increased (Fig. 3) is likely to extend to situations where inoculum sources exist in other crops or noncrop habitats. For example, on the North Coast of California (e.g., Napa and Sonoma counties), native plants in riparian habitats are important sources of primary inocula for spread of $X$. fastidiosa to grapevines by the blue-green sharpshooter $(11,38,40)$. As roguing within riparian habitats is impractical, such habitats are equivalent to unmanaged farms. Accordingly, it is reasonable to expect the risk of primary pathogen spread into a vineyard to increase as the percentage of surrounding riparian areas increase.

Conclusions. One of the challenges associated with managing the spread of invasive and/or rapidly spreading plant pathogens is that management strategies must often be implemented prior to or with limited field testing. For example, epidemics of Pierce's disease in southern California in the late 1990s due to introduction of an exotic vector required immediate action $(49,53)$. Similarly, detection of the Asian citrus psyllid (primary vector of ' $\mathrm{Ca}$. Liberibacter spp.') in 2008 (2) and an HLB-affected tree in 2012 (3) in California required immediate action. For situations where immediate action is required, simulation models provide a transparent and rigorous method for evaluating a wide range of man- 
agement tactics to gain insight into which strategies may be most effective at suppressing pathogen spread. The models presented here were purposefully simple so that they could be applied to a broad array of systems, with a specific goal of emphasizing the effects of rate of tree removal on the quantity of trees removed and ultimately yield. While roguing as a control strategy was emphasized, management is most likely to be successful when diverse tactics are applied. For example, roguing was more effective at suppressing pathogen spread with low rates of primary and secondary pathogen spread compared with simulations with high rates of primary and secondary pathogen spread (Figs. 2 and 3). For vector-transmitted pathogens, rates of pathogen spread are dependent on factors affecting vector behavior (i.e., factors affecting vector movement among plants and transmission efficiency) and vector density (number of vectors per plant) $(30,31,42,43)$. Thus, for vector-transmitted pathogens roguing/plant replacement is likely to be most successful when combined with vector management strategies that reduce rates of primary and secondary pathogen spread.

\section{ACKNOWLEDGMENTS}

Mention of trade names or commercial products in this publication is solely for the purpose of providing specific information and does not imply recommendation or endorsement by the U.S. Department of Agriculture. USDA is an equal opportunity provider and employer.

\section{LITERATURE CITED}

1. Allen, R. N. 1978. Epidemiological factors influencing the success of roguing for the control of bunch top disease of bananas in New South Wales. Austral. J. Agric. Res. 29:535-544.

2. Anonymous. 2008. Single Asian citrus psyllid detected in San Diego. California Department of Food and Agriculture. Sacramento, CA. Press Release \#08-057.

3. Anonymous. 2012. Citrus disease huanglongbing detected in Hacienda Heights area of Los Angeles County. California Department of Food and Agriculture. Sacramento, CA. Press Release \#12-012.

4. Bar-Joseph, M., Marcus, R. and Lee, R. F. 1989. The continuous challenge of citrus tristeza virus control. Ann. Rev. Phytopathology 27:291316.

5. Barnier, J., Grafton-Cardwell, B., and Polek, M. 2010. Citrus tristeza virus (CTV): Then and now. Citrograph Nov./Dec. 16-23.

6. Belasque, J., Bassanezi, R. B., Yamamoto, P. T., Ayres, A. J., Tachibana, A., Violante, A. R., Tank, A., Di Giorgi, F., Tersi, F. E. A., Menezes, G. M., Dragone, J., Jank, R. H., and Bove, J. M. 2010. Lessons from huanglongbing management in São Paulo State, Brazil. J. Plant Pathol. 92:285-302.

7. Boina, D. R., Meyer, W. L., Onagbola, E. O., and Stelinski, L. L. 2009. Quantifying dispersal of Diaphorina citri (Hemiptera: Psyllidae) by immunomarking and potential impact of unmanaged groves on commercial citrus management. Environ. Entomol. 38:1250-1258.

8. Cabrera-La Rosa, J. C., Johnson, M. W., Civerolo, E. L., Chen, J., and Groves, R. L. 2008. Seasonal population dynamics of Draeculacephala minerva (Hemiptera: Cicadellidae) and transmission of Xylella fastidiosa. J. Econ. Entomol. 101:1105-1113.

9. Caprio, M. A., Storer, N., Sisterson, M. S., Peck, S., and de Holanda Nunes Maia, A. 2008. Assessing the risk of the evolution of resistance to pesticides using spatially complex simulation models. Pages 90-117 in: Global Pesticide Resistance in Arthropods. M. E. Whalon, D. MotaSanchez, and R. M. Hollingworth, eds. CAB International, Wallingford, UK.

10. Chan, M.-S., and Jeger, M. J. 1994. An analytical model of plant virus disease dynamics with roguing and replanting. J. Appl. Ecol. 31:413-427.

11. Coletta-Filho, H. D., Bittleston, L. S., and Almeida, R. P. P. 2011. Spatial genetic structure of a vector-borne generalist pathogen. Appl. Environ. Microbiol. 77:2596-2601.

12. Daane, K. M., Wistrom, C. M., Shapland, E. B., and Sisterson, M. S. 2011. Seasonal abundance of Draeculacephala minerva and other Xylella fastidiosa vectors in California almond orchards and vineyards. J. Econ. Entomol. 104:367-374

13. Dallot, S., Gottwald, T., Labonne, G., and Quiot, J.-B. 2004. Factors affecting the spread of Plum pox virus strain $\mathrm{M}$ in peach orchards subjected to roguing in France. Phytopathology 94:1390-1398.

14. Daniells, J. W., Geering, A. D. W., Bryde, M. J., and Thomas, J. E. 2001.
The effect of Banana streak virus on the growth and yield of dessert bananas in tropical Australia. Ann. Appl. Biol. 139:51-60.

15. Domfeh, O., Dzahini-Obiatey, H., Ameyaw, G. A., Abaka-Ewusie, K., and Opoku, G. 2011. Cocoa swollen shoot virus disease situation in Ghana: A review of current trends. African J. Agric. Res. 6:5033-5039.

16. Dzahini-Obiatey, G., Ameyaw, A., and Ollennu, L. A. 2006. Control of cocoa swollen shoot disease by eradicating infected trees in Ghana: A survey of treated and replanted areas. Crop Prot. 25:647-652.

17. Dzahini-Obiatey, H., Domfeh, O., and Amoah, F. M. 2010. Over seventy years of a viral disease of cocoa in Ghana: From researchers' perspective. African J. Agric. Res. 5:476-485.

18. Edwin, J., and Masters, W. A. 2005. Genetic improvement and cocoa yields in Ghana. Exp. Agric. 41:491-503.

19. Fauquet, C., and Fargette, D. 1990. African cassava mosaic virus: Etiology, epidemiology, and control. Plant Dis. 74:404-411.

20. Fereres, A., and Moreno, A. 2009. Behavioral aspects influencing plant virus transmission by homopteran insects. Virus Res. 141:158-168.

21. Fishman, S., and Marcus, R. 1984. A model for spread of plant disease with periodic removals. J. Mathematical Biol. 21:149-158.

22. Folimonova, S. Y., Robertson, C. J., Garnsey, S. M., Gowda, S., and Dawson, W. O. 2009. Examination of the responses of different genotypes of citrus to huanglongbing (citrus greening) under different conditions. Phytopathology 99:1346-1354.

23. Georghiou, G. P., and Taylor, C. E. 1977. Operational influences in the evolution of insecticide resistance. J. Econ. Entomol. 70:653-658.

24. Goodwin, P., and Purcell, A. H. 1992. Pierce's disease. Pages 76-84 in: Grape Pest Management. D. L. Flaherty, L. P. Christensen, W. T. Lanini, J. J. Marois, P. A. Phillips, and L. T. Wilson, eds. University of California, Division of Agriculture and Natural Resource, Oakland.

25. Gottwald, T. R. 2010. Current epidemiological understanding of citrus huanglongbing. Annu. Rev. Phytopathol. 48:119-139.

26. Gottwald, T. R., Garnsey, S. M., and Riley, T. D. 2002. Latency of systemic infection in young field-grown sweet orange trees following graft-inoculation with Citrus tristeza virus. Pages 48-53 in: Proc. 15th Conf. Int. Organ. Citrus Virol. IOCV, Riverside, CA.

27. Gottwald, T. R., Graham, J. H., Isrey, M. S., McCollum, T. G., and Wood, B. W. 2012. Inconsequential effect of nutritional treatments on huanglongbing control, fruit quality, bacterial titer and disease progress. Crop Prot. 36:73-82

28. Gould, F., Cohen, M. B., Bentur, J. S., Kennedy, G. G., and Van Duyn, J. 2006. Impact of small fitness costs on pest adaptation to crop varieties with multiple toxins: A heuristic model. J. Econ. Entomol. 99:2091-2099.

29. Hewitt, W. B., Frazier, N. W., Freitag, J. H., and Winkler, A. J. 1949. Pierce's disease investigations. Hilgardia 19:207-262.

30. Jeger, M. J., Holt, J., Van Den Bosch, F., and Madden, L. V. 2004. Epidemiology of insect-transmitted plant viruses: Modeling disease dynamics and control interventions. Physiol. Entomol. 29:291-304.

31. Jeger, M. J., Van Den Bosch, F., Madden, L. V., and Holt, J. 1998. A model for analysing plant-virus transmission characteristics and epidemic development. IMA J. Math. Appl. Medicine Biol. 15:1-18.

32. Lampinen, B. D., Connell, J. H., Verdegall, P., Viveros, M., Metcalf, S. G., Negron, C., Thorpe, M. A., Gradziel, T. M., and Micke, W. C. 2006. Progress report: Regional almond variety trials planted in 1993. University of California Progress Report 83806

33. Muraro, R. P., and Castle, W. S. 1996. Resetting and replanting options in Florida citrus groves and the financial consequences. Proc. Fla. State Hort. Soc. 109:128-131.

34. Peacock, W. L., Vasquez, S. J., Hashim, J. M., Fidelibus, M. W., Leavitt, G. M., Klonsky, K. M., and De Moura, R. L. 2006. Sample costs to establish and a vineyard and produce grapes for raisins: Tray dried raisin San Joaquin Valley. University of California Cooperative Extension publication number GR-SJ-06-1.

35. Peck, S. L. 2004. Simulation as experiment: A philosophical reassessment for biological modeling. Trends Ecol. Evol. 19:530-534.

36. Peck, S. L., Gould, F., and Ellner, S. P. 1999. Spread of resistance in spatially extended regions of transgenic cotton: Implications for management of Heliothis virescens (Lepidoptera: Noctuidae). J. Econ. Entomol. 92:1-16.

37. Polek, M., Gumpf, D. J., Wallen, C. M., and Riley, K. M. 2005. Biological characterization of naturally occurring Citrus tristeza virus strains in California citrus. Pages 68-74 In: Proc. 16th Conf. Int. Organ. Citrus Virol. IOCV, Riverside, CA.

38. Purcell, A. 1974. Spatial patterns of Pierce's disease in the Napa Valley. Am. J. Enol. Viticult. 25:162-167.

39. Purcell, A. H., and Frazier, N. W. 1985. Habitats and dispersal of the principal leafhopper vectors of Pierce's disease in the San Joaquin Valley. Hilgardia 53:1-32.

40. Purcell, A. H., and Saunders, S. R. 1999. Fate of Pierce's disease strains of Xylella fastidiosa in common riparian plants in California. Plant Dis. 83:825-830. 
41. Shapland, E. B., Daane, K. M., Yokota, G. Y., Wistrom, C., Connell, J. H., Duncan, R. A., and Viveros, M. A. 2006. Ground vegetation survey for Xylella fastidiosa in California almond orchards. Plant Dis. 90:905-909.

42. Sisterson, M. S. 2008. Effects of insect-vector preference for healthy or infected plants on pathogen spread: Insights from a model. J. Econ. Entomol. 101:1-8.

43. Sisterson, M. S. 2009. Transmission of insect-vectored pathogens: Effects of vector fitness as a function of infectivity status. Environ. Entomol. 38:345-355.

44. Sisterson, M. S., Antilla, L., Carrière, Y., Ellers-Kirk, C., and Tabashnik, B. E. 2004. Effects of insect population size on evolution of resistance to transgenic crops. J. Econ. Entomol. 97:1413-1424.

45. Sisterson, M. S., Carrière, Y. Dennehy, T. J., and Tabashnik, B. E. 2005. Evolution of resistance to transgenic crops: Interactions between insect movement and field distribution. J. Econ. Entomol. 98:1751-1762.

46. Sisterson, M. S., Chen, J., Viveros, M. A., Civerolo, E. L., Ledbetter, C., and Groves, R. L. 2008. Effects of almond leaf scorch disease on almond yield: Implications for management. Plant Dis. 92:409-414.

47. Sisterson, M. S., Ledbetter, C. A., Chen, J., Higbee, B. S., Groves, R. L., and Daane, K. M. 2012. Management of almond leaf scorch disease: Long term data on yield, tree vitality, and disease progress. Plant Dis. 96:1037-1044.

48. Sisterson, M. S., Thammiraju, S. R., Lynn-Patterson, K., Groves, R. L., and Daane, K. M. 2010. Epidemiology of diseases caused by Xylella fastidiosa in California: Evaluation of alfalfa as a source of vectors and inocula. Plant Dis. 94:827-834.

49. Sisterson, M. S., Yacoub, R., Montez, G., Grafton-Cardwell, E. E., and Groves, R. L. 2008. Distribution and management of citrus in California: Implications for management of glassy-winged sharpshooters. J. Econ. Entomol. 101:1041-1050.

50. Spann, T., and Schumann, A. 2012. Using good horticultural practices to maintain yield of HLB-affected groves. Citrus Industry June:6-11.

51. Spann, T. M., Atwood, R. A., Dewdney, M. M., Ebel, R. C., Ehsani, R., England, G., Futch, S. H., Gaver, T., Hurner, T., Oswalt, C., Rogers, M. E., Roka, F. M., Ritenour, M. A., Zekri, M., Boman, B. J., Chung, K.-R., Danyluk, D., Goodrich-Schneider, R., Morgan, K. T., Morris, R. A.,
Muraro, R. P., Roberts, P., Rouse, R. E., Schumann, A. W., Stansly, P. A., and Stelinski, L. L. 2010. IFAS Guidance for Huanglongbing (Greening) Management. IFAS Publication number HS1165. University of Florida Institute of Food and Agricultural Sciences, Gainesville, FL.

52. Spharim, I., and Shalhevet, S. 1988. Formulating policy to cope with virus disease in citrus orchards. Agric. Syst. 27:215-224.

53. Stenger, D. C., Sisterson, M. S., and French, R. 2010. Population genetics of Homalodisca vitripennis reovirus validates timing and limited introduction to California of its invasive insect host, the glassy-winged sharpshooter. Virology 407:53-59.

54. Tabashnik, B. E., Gassmann, A. J., Crowder, D. W., and Carrière, Y. 2008. Insect resistance to Bt crops: Evidence versus theory. Nat. Biotechnol. 26:199-202.

55. Tabashnik, B. E., Sisterson, M. S., Ellsworth, P. C., Dennehy, T. J., Antilla, L., Liesner, L., Whitlow, M., Staten, R. T., Fabrick, J. A., Unnithan, G. C., Yelich, A. J., Ellers-Kirk, C., Harpold, V. S., Li, X., and Carrière, Y. 2010. Suppressing resistance to Bt cotton with sterile insect releases. Nat. Biotechnol. 28:1304-1307.

56. Thresh, J. M., and Owusu, G. K. 1986. The control of cocoa swollen shoot disease in Ghana: An evaluation of eradication procedures. Crop Prot. 5:41-52.

57. Tiwari, S., Lewis-Rosenblum, H., Pelz-Stelinski, K., and Stelinski, L. L. 2010. Incidence of Candidatus Liberibacter asiaticus infection in abandoned citrus occurring in proximity to commercially managed groves. J. Econ. Entomol. 103:1972-1978.

58. Van den Bosch, F., and de Roos, A. M. 1996. The dynamics of infectious disease in orchards with roguing and replanting as control strategy. J. Mathematical Biol. 35:129-157.

59. Vasquez, S. J. H., Buckey, J. M., Peacock, W. L., Klonsky, K. M., and De Moura, R. L. 2007. Samples costs to establish and produce table grapes: San Joaquin Valley South. University of California Cooperative Extension publication number GR-VS-07-1.

60. Yokomi, R. K., and DeBorde, R. L. 2005. Incidence, transmissibility, and genotype analysis of Citrus tristeza virus (CTV) isolates from CTV eradicative and noneradicative districts in central California. Plant Dis. 89:859-866. 